\title{
Floristic and phytogeographic pattern of native field in southeastern Brazil
}

\author{
Vanuza Borges Ribeiro Ferreira ${ }^{1,3}$, Marcelo Trindade Nascimento ${ }^{2}$ and Luis Fernando Tavares de Menezes ${ }^{1}$
}

Received: October 9, 2012. Accepted: April 28, 2014

\begin{abstract}
The waterlogging of soils creates selective environments for plant species. The frequency and duration of flooding influence the responses to ecological processes, determining the structure and floristic composition of vegetation formations. We investigated the relationship between floristic composition and environmental heterogeneity of native field, one physiognomic type found interspersed with semideciduous forest in the plains in the northern part of the state of Espírito Santo, Brazil, which is characterized by varying degrees of waterlogging. Our results indicate that the differentiation of physiognomic types of native field is related to the frequency and duration of waterlogging to which each is subjected, resulting in a somewhat shared flora, dominated by phanerophytes. Flooding was also found to account for differences between the areas analyzed in terms of the soil $\mathrm{pH}$, which ranged from strongly acid to extremely acid. The geographic proximity between the native field studied and areas of muçununga (or mussununga, a coastal forest ecosystem associated with the Atlantic Forest) did not increase the floristic similarity between the two.
\end{abstract}

Key words: Atlantic Forest, groundwater depth, muçununga, Vale Nature Reserve, soil

\section{Introduction}

The status of the water table is one of the most influential factors affecting the diversity, structural complexity and dynamics of vegetation formations (Scarano et al. 1997). The duration and periodicity of flooding, for example, determine several ecological processes, such as the productivity, distribution, demography and reproductive biology of plant populations (Junk et al. 1989; Megonigal et al. 1997). Ecological models (Odum 1979) suggest that, for a given vegetation formation, long periods of flooding decrease productivity, whereas periodic flooding can increase productivity (Megonigal et al. 1997).

The waterlogging of soils creates highly selective environments for plant species by reducing or eliminating soil oxygenation (Lieberman et al. 1985; Joly 1991). Such stressful environments come to be dominated by a few species with large populations and high biomasses, typically displaying low diversity in comparison with vegetation formations established in well-drained soils (Teixeira \& Assis 2009; Scarano 2006). The presence of well-drained sites can increase the local diversity of the flora of floodplain vegetation formations (Menezes et al. 2010) by allowing the establishment of species that are less tolerant to water saturation, which prevail in the neighboring vegetation formations (Scarano 2002; Rocha et al. 2005; Teixeira et al. 2008). Therefore, floristic and structural differences can be observed between different sites within the same vegetation formation, because of different drainage conditions (Loures et al. 2007; Teixeira et al. 2008) and of influence from the neighboring vegetation (Ivanauskas et al. 1997; Teixeira \& Assis 2009).

Although the relationship between the structure of vegetation formations and local environmental variations has been investigated, especially in forest formations (e.g. Joly \& Crawford 1982; Oliveira Filho et al. 1990; Felfili 1995; Souza \& Martins 2005; Damasceno Junior et al. 2005), little is known about the plant ecology of the wetlands of the Atlantic Forest Biome in southeastern Brazil (Scarano et al. 2005), and even less is known about species distribution in relation to the environmental characteristics of such wetlands on a small spatial scale (Teixeira \& Assis 2009).

This study analyzed the floristic composition of native fields, a physiognomy found within the so-called tabuleiro forests (coastal lowland forests on Tertiary deposits) in the northern part of the state of Espírito Santo, Brazil (Veloso et al. 1991). Native fields occur interspersed with a forest type known as muçununga (or mussununga, a coastal forest ecosystem associated with the Atlantic Forest), as described by Peixoto et al. (2008). Physiognomically, the muçununga differs from the native field, because the former is composed of tree species of up to $30 \mathrm{~m}$ in height, whereas the latter is composed of graminoids and shrubs.

\footnotetext{
${ }^{1}$ Centro Universitário Norte do Espírito Santo - CEUNES/UFES, Rodovia BR 101 Norte, Km 60, Bairro Litorâneo - São Mateus, ES, $29932-540$

${ }^{2}$ Universidade Estadual do Norte Fluminense Darcy Ribeiro - UENF, Av. Alberto Lamego, 2000- Horto - Campos dos Goytacazes, RJ, 28013-600

${ }^{3}$ Author for correspondence: vanuzabrf@gmail.com
} 
The few studies performed in native fields have focused on their flora, physiognomy and origin (Heinsdijk et al. 1965; Veloso \& Góes-Filho 1982; Peixoto 1982; Peixoto \& Gentry 1990; Araujo et al. 2008). Native fields can be categorized into four types, considering the physiognomy and frequency of the species: dense graminoid, graminoid, closed shrubland and open shrubland. The first three refer to native fields on Tertiary soils and the last refers to native fields on Quaternary soils, which, in fact, constitute a vegetation formation known as restinga (coastal woodland) on Pleistocene soils (Suguio \& Dominguez 1982).

Assuming the premise that the duration and periodicity of flooding are responsible for differences in diversity, richness and structure among vegetation formations within the same phytogeographic unit, we investigated the relation between the floristic composition and the environmental heterogeneity of two native fields in the Vale Natural Reserve (municipality of Linhares, Espírito Santo). Our hypothesis is that the floristic composition differs between these native fields, even at a small spatial scale (a few hundred meters of distance from one field to another), and that such difference is related to the different levels of soil waterlogging found in each vegetation formation. Additionally, another hypothesis is that the flora of the areas of muçununga is the main source of propagules to the native fields, due to their proximity.

\section{Material and methods}

\section{Study sites}

The Vale Natural Reserve is located in the Doce river watershed, in the northern part of Espírito Santo $\left(19^{\circ} 06^{\prime}\right.$ to $19^{\circ} 18^{\prime} \mathrm{S}$; $39^{\circ} 45^{\prime}$ to $40^{\circ} 19^{\prime} \mathrm{W}$ ), and occupies approximately 22,000 hectares (Fig. 1). According to the Köppen classification system (Köppen 1946), the climate of the region is type Awi (tropical wet-dry isothermal), with rainy summers and dry winters. Jesus et al. (2010) analyzed 26 years of data from the meteorological station within the reserve and reported a mean annual rainfall of $1202 \mathrm{~mm}$, noting that June, July and August were the driest months. The mean annual temperature is $23.3^{\circ} \mathrm{C}$, the monthly mean ranging from $14.8^{\circ} \mathrm{C}$ to $34.2^{\circ} \mathrm{C}$. The mean annual relative air humidity has ranged from $82.1 \%$ to $84.7 \%$ the monthly means ranging from $80.6 \%$ to $86.6 \%$

The native fields within the Vale Natural Reserve occur on sandy, nutrient-poor soils. The first layer of the soil does not exceed a depth of $60 \mathrm{~cm}$, at which there is aggregation of fine roots; in this aspect, the native fields resemble muçununga forests (Garay 2003). The water table frequently lies below that depth. These soils are under an intense podzolization process, which is accentuated by hydromorphism

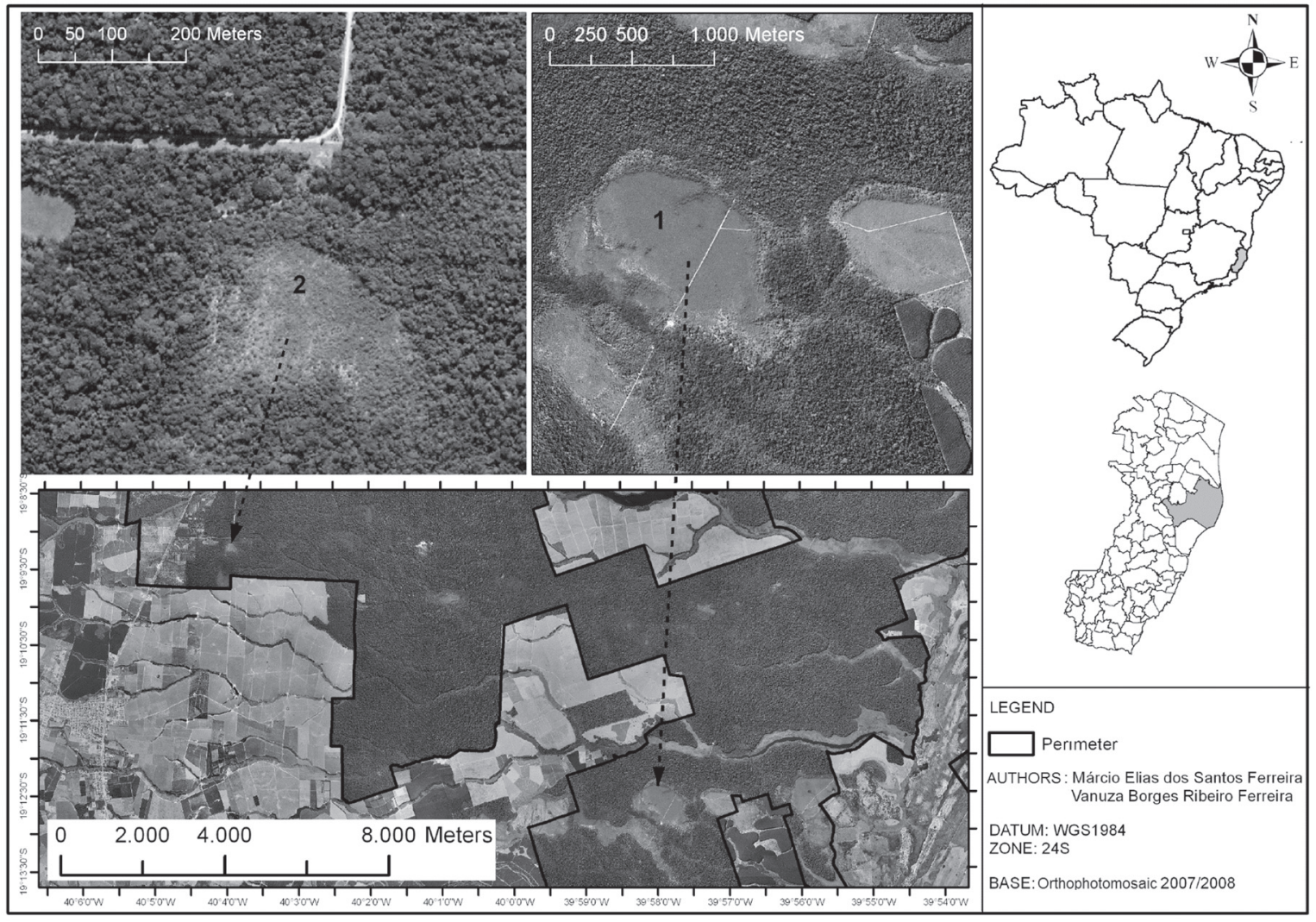

Figure 1. Map of Vale Nature Reserve detailing the native field studied in the state of Espírito Santo, Brazil. 1) Gávea site; 2) Roxinho site. 
(Jesus \& Rolim 2005). According to Santos et al. (2004), native fields occur on Spodosols, derived mainly from sand and quartzite, formed under high humidity, in tropical and subtropical climates. This soil type occurs in plain, slightly undulated relief; in areas of natural springs and depressions; under different vegetation types (Embrapa 1999). In the native fields studied, water availability is affected by the fact that the level of the water table varies considerably, according to the rainfall regime, between periods of flooding and water restriction.

Of the various native field formations that occur in the Vale Natural Reserve, two were selected because of the physiognomic differences between them. These two sites, known locally as Gávea and Roxinho, have not been subjected to significant disturbance related to human activity for at least fifty years. Both sites are circular and are surrounded by muçununga forest (Fig. 1), showing a transition zone that is characterized by a gradual increase in the number of woody individuals and a decrease in the abundance of graminoid life forms.

The Gávea native field ( $19^{\circ} 12^{\prime} \mathrm{S}$; $\left.39^{\circ} 57^{\prime} \mathrm{W}\right)$ occupies 85 ha. It is almost completely covered by the dominant grasses and sedges, with few patches of bare soil. A thin sheet of water $(\leq 10 \mathrm{~cm})$ can be observed covering the soil during the rainy season.

The Roxinho native field ( $\left.19^{\circ} 09^{\prime} \mathrm{S} ; 40^{\circ} 03^{\prime} \mathrm{W}\right)$ occupies 4.75 ha. Within this site, shrubs are noticeably more abundant than in the Gávea native field. Grasses and sedges are interspersed with patches of bare soil. Although the soil is flooded in the rainy season, sheets of water cover the soil only occasionally, when the rainfall is above average.

\section{Floristic survey and vegetation analysis}

Surveys were performed between April 2010 and September 2011. The botanical material was preserved according to Mori et al. (1989) and deposited in the Herbarium of the Federal University of Espírito Santo in Vitória, Brazil (code, VIES), with duplicates in the Herbarium of the Vale Natural Reserve in Linhares, Brazil (code, CVRD). Species were identified in the field, whenever possible, or by consulting the literature and specialists at CVRD. The botanical families were listed alphabetically according to the Angiosperm Phylogeny Group III guidelines (APG III 2009).

The species were classified by life form, following the Raunkiaer system, as adapted by Mueller-Dombois \& Ellenberg (1974), considering mainly the position of the buds on the plant. The proportional distributions of species by life form in the different vegetation formations were compared by the chi-square test (Zar 1996).

For the floristic comparison with other vegetation formations on sandy soils in Espírito Santo and in the neighboring state of Bahia, we consulted 18 floristic lists from studies conducted in native fields, areas of muçununga and areas of restinga (Tab. 1). We built a presence/absence matrix for the multivariate analyses, using the unweighted pair group method with arithmetic mean (Chatfield \& Collins 1983) and the Jaccard similarity index (Kent \& Coker 1992), calculated with the Multivariate Statistics Package MVSP, version 3.1 (Kovach Computing Services, Pentraeth, Wales). We verified botanical synonyms and considered only taxa identified to the species level.

Table 1. List of works used for analysis of floristic similarity of vegetation on sandy soils in the Espírito Santo and Bahia.

\begin{tabular}{|c|c|c|c|}
\hline \multicolumn{2}{|c|}{ Locations } & \multirow{2}{*}{$\begin{array}{l}\text { Physiognomy } \\
\text { native grasslands }\end{array}$} & \multirow{2}{*}{$\begin{array}{l}\text { References } \\
\text { Araújo et al. } 2008\end{array}$} \\
\hline A & Ceolin - Linhares/ES & & \\
\hline $\mathrm{B}$ & Macanaíba - Linhares/ES & native grasslands & Araújo et al. 2008 \\
\hline $\mathrm{C}$ & Parajú e Barra Seca - Linhares/ES & native grasslands & Araújo et al. 2008 \\
\hline $\mathrm{D}$ & Gávea - Linhares/ES & native grasslands & Our data \\
\hline $\mathrm{E}$ & Roxinho- Linhares/ES & native grasslands & Our data \\
\hline $\mathrm{F}$ & Mucurí/BA & Muçununga & Meira Neto 2005 \\
\hline G & Caravelas/BA & Muçununga & Meira Neto 2005 \\
\hline $\mathrm{H}$ & Linhares/ES & Muçununga & Simonelli 2008 \\
\hline I & Caravelas/BA & Muçununga & Saporetti Jr. 2009 \\
\hline $\mathrm{J}$ & Caravelas/BA & Muçununga & Saporetti Jr. 2009 \\
\hline $\mathrm{K}$ & Caravelas/BA & Muçununga & Saporetti Jr. 2009 \\
\hline $\mathrm{L}$ & Caravelas/BA & Muçununga & Saporetti 2009 \\
\hline M & Caravelas/BA & Muçununga & Saporetti 2009 \\
\hline $\mathrm{N}$ & Caravelas/BA & Muçununga & Saporetti 2009 \\
\hline $\mathrm{O}$ & Setiba/ES & Restinga & Assis et al. 2004 \\
\hline $\mathrm{P}$ & Regência/ES & Restinga & Colodete \& Pereira 2007 \\
\hline Q & Fazenda São Jorge/ES & Restinga & Pereira \& Assis 2004 \\
\hline $\mathrm{R}$ & Fazenda São Jorge/ES & Restinga & Pereira et al. 2004 \\
\hline S & Maraú/BA & Restinga & Souza 2008 \\
\hline $\mathrm{T}$ & Salvador/BA & Restinga & Britto et al. 1993 \\
\hline
\end{tabular}




\section{Collection and analysis of environmental variables}

To evaluate the variation in the water table, we installed observation wells, randomly distributed throughout the two study sites (five wells per site). In brief, we perforated the soil with an auger and inserted perforated PVC tubes (40 $\mathrm{mm}$ in diameter and $1 \mathrm{~m}$ in length) into the soil. The PVC tubes were wrapped in nylon mesh to facilitate water percolation and prevent sand from entering. At the bottom of each well, we placed a thin layer of gravel, which acted as a filter. To keep rainwater out, we sealed the top of the tube with a plug.

The water table depth was measured with a ruler, considering the distance from the surface of the soil to the waterline. These measurements were performed once a month for twelve months (October 2010 to September 2011). When there was no water at the pre-established depth of $1 \mathrm{~m}$, we recorded the value as $>1 \mathrm{~m}$.

For soil sampling, we traced 10 lines within each study site. The lines were $50 \mathrm{~m}$ in length, at least $20 \mathrm{~m}$ apart and at least $20 \mathrm{~m}$ from the border of the vegetation. From under each line, we collected composite soil samples at a depth of $20 \mathrm{~cm}$. Each composite soil sample consisted of sub-samples collected at three points, $5 \mathrm{~m}$ apart, with $10 \mathrm{~m}$ between each composite soil sample collection zone. We collected 30 composite soil samples from each study site. The samples were air-dried, crumbled and sifted with a 2-mm mesh sieve to obtain fine soil. To describe the texture of the soil of each study site, we mixed samples to create a single sample per site, in which we analyzed the sand, silt and clay contents. The chemical and physical analyses of the soil were performed at the Laboratory of Agronomic Soil Analyses of the Federal University of Espírito Santo Northern Espírito Santo University Center, according to the procedures established by the Brazilian Agency for Agricultural Research (Embrapa 1997).

\section{Data analysis}

To test whether the mean water table depth varied between the environments, we performed repeated measures ANOVA. For the soil chemical variables, we calculated the means per study site and compared them by ANOVA, at 5\% probability, followed by Tukey's test (Zar 1996).

\section{Results and discussion}

\section{Floristic analysis}

At the Gávea site, we recorded 36 species within 36 genera and 21 families, compared with 43 species within 42 genera and 27 families at the Roxinho site (Tab. 2). The only pteridophyte species, Polypodium latipes Langsd. \& Fisch, was found at the Roxinho site. Guapira was the only genus represented by more than one species at the two study sites.
At the family level, the similarity between the two sites was $59 \%$. We recorded 20 and 24 species that were exclusive to the Gávea and Roxinho sites, respectively. The two sites had 17 species in common, corresponding to $39.5 \%$ of the species recorded at the Roxinho site and $47 \%$ of those recorded at the Gávea site. The high proportion of species exclusive to each site, that is, the variation in species composition at a small spatial scale (within a few hundred meters) reflects the selectivity of these sites, due to edaphic influences (Teixeira \& Assis 2009). The native field at the Gávea site is subjected to stronger environmental stressors (longer and more intense periods of seasonal flooding) than is that at the Roxinho site. Those stressors restrict the establishment of species at the Gávea site, as reported by Scarano (1998), who studied the dispersal, germination and establishment of plants subjected to different flooding regimes and the consequences of the oxygen deficit imposed by flooded soils. Studies performed in areas of restinga showed that floodplain vegetation formations display a lower richness of plant species than upland vegetation formations (Almeida Jr. et al. 2009, Guedes et al. 2006, Menezes et al. 2010). Therefore, variations in the frequency and intensity of soil waterlogging can be considered determinants of the structural and floristic characteristics of the vegetation. Such variations might also result in altered behavior for certain populations (Rodrigues \& Shepherd 2000; Menezes et al. 2010).

At the two study sites, we observed that many families were represented by a small number of species, a high proportion of the families being represented by only one or two species. In the Gávea native field, the families with the highest richness were Melastomataceae, with four species; Apocynaceae and Eriocaulaceae, with three each; and Asteraceae, Dilleniaceae, Humiriaceae, Lauraceae, Myrtaceae, Orchidaceae and Rubiaceae, with two each. The remaining families, accounting for $28 \%$ of the richness, were represented by only one species. In the Roxinho native field, the families with the highest richness were Eriocaulaceae, Myrtaceae, Orchidaceae and Rubiaceae, with three species each; and Asteraceae, Bignoniaceae, Dilleniaceae, Fabaceae, Humiriaceae, Melastomataceae and Nyctaginaceae, with two each. Another 15 families (55.5\%) were represented by a single species. Studies performed in areas of restinga also showed that the proportion of families represented by more than one species was low (Pereira \& Araujo 2000; Scherer et al. 2005; Amaral et al. 2008). Most families found in the native fields studied here are shared with the non-forested areas of muçununga in the south of Bahia (Meira Neto et al. 2005; Saporetti Jr. 2009; Sarcinelli 2010).

\section{Life forms}

Regarding the biological spectrum of the two sites, there was no significant difference in the distribution of the number of species per life form $\left(\mathrm{df}=6 ; \chi^{2=12.592 ;} p>0.01\right)$. Phanerophytes constituted the most common life form 
Table 2. Families and species sampled in two communities of native field in the north of the Espírito Santo. Lifeforms. CAM-chamaephytes; EPI-Epiphyte, FANphanerophytes; HEM-hemicryptophytes; LIA- creeper; TER-therophyte.

\begin{tabular}{|c|c|c|c|}
\hline Family/Species & FV & Gávea & Roxinho \\
\hline \multicolumn{4}{|l|}{ APOCYNACEAE } \\
\hline Himatanthus bracteatus (A. DC.) Woodson & FAN & $\mathrm{x}$ & \\
\hline Ditassa nitida E. Fourn.* & LIA & $\mathrm{x}$ & \\
\hline Peplonia asteria (Vell.) Fontella \& E.A. Schwarz ${ }^{*}$ & LIA & $\mathrm{x}$ & $\mathrm{x}$ \\
\hline ARACEAE & & & $\mathrm{x}$ \\
\hline Anthurium queirozianum Nadruz sp.nov.ined. & HEM & & $\mathrm{x}$ \\
\hline \multicolumn{4}{|l|}{ ASTERACEAE } \\
\hline Chromolaena squalida (DC.) K. \& R. & FAN & & $\mathrm{x}$ \\
\hline Eupatorium harvardianum Steyerm. & FAN & $\mathrm{x}$ & $\mathrm{x}$ \\
\hline Vernonia scorpioides Pers. & CAM & $\mathrm{x}$ & $\mathrm{x}$ \\
\hline \multicolumn{4}{|l|}{ BIGNONIACEAE } \\
\hline Tabebuia elliptica (DC.) Sandwith* & FAN & $\mathrm{x}$ & $\mathrm{x}$ \\
\hline Bignonia corymbosa (Vent.) L.G. Lohmann & LIA & & $\mathrm{x}$ \\
\hline \multicolumn{4}{|l|}{ BONNETIACEAE } \\
\hline Bonnetia stricta (Nees) Nees \& Mart. & FAN & $\mathrm{x}$ & \\
\hline \multicolumn{4}{|l|}{ BROMELIACEAE } \\
\hline Vriesea procera Mart. \& Schult & CAM & $\mathrm{x}$ & $\mathrm{x}$ \\
\hline Tillandsia stricta Solander ex Ker - Gawler & EPI & & $\mathrm{x}$ \\
\hline \multicolumn{4}{|l|}{ BURSERACEAE } \\
\hline Protium icicariba var. talmonii Daly* & FAN & & $\mathrm{x}$ \\
\hline \multicolumn{4}{|l|}{ CACTACEAE } \\
\hline Pereskia aculeata Mill. & LIA & & $\mathrm{x}$ \\
\hline \multicolumn{4}{|l|}{ CHRYSOBALANACEAE } \\
\hline Hirtella corymbosa Cham. \& Schltdl. & FAN & & $\mathrm{x}$ \\
\hline Hirtella sp. & FAN & $\mathrm{x}$ & \\
\hline \multicolumn{4}{|l|}{ CLUSIACEAE } \\
\hline Kielmeyera membranacea Casar.* & FAN & & $\mathrm{x}$ \\
\hline \multicolumn{4}{|l|}{ CYPERACEAE } \\
\hline Lagenocarpus rigidus (Kunth) Nees & HEM & $\mathrm{x}$ & $\mathrm{x}$ \\
\hline \multicolumn{4}{|l|}{ DILLENIACEAE } \\
\hline Davilla flexuosa A.St.-Hil.* & LIA & $\mathrm{x}$ & $\mathrm{x}$ \\
\hline Doliocarpus lancifolius Kubitzki*** & FAN & $\mathrm{x}$ & $\mathrm{x}$ \\
\hline \multicolumn{4}{|l|}{ ERICACEAE } \\
\hline Gaylussacia brasiliensis (Spreng.) Meisn. & FAN & $\mathrm{x}$ & $\mathrm{x}$ \\
\hline \multicolumn{4}{|l|}{ ERIOCAULACEAE } \\
\hline Leiothrix hirsuta Ruhl. & TER & $\mathrm{x}$ & $\mathrm{x}$ \\
\hline Syngonanthus gracilis (Koern) Rubl. & TER & $\mathrm{x}$ & \\
\hline Paepalanthus klotzschianus Koern.* & TER & & $\mathrm{x}$ \\
\hline Actinocephalus ramosus ( Wikstr.) P.T. Sano & TER & $\mathrm{x}$ & $\mathrm{x}$ \\
\hline \multicolumn{4}{|l|}{ FABACEAE } \\
\hline Andira fraxinifolia Benth. & FAN & & $\mathrm{x}$ \\
\hline Hymenolobium alagoanum var. parvifolium Lima & FAN & $\mathrm{x}$ & \\
\hline Chamaecrista ramosa (Vog.) Irw. et Barn. & CAM & & $\mathrm{x}$ \\
\hline \multicolumn{4}{|l|}{ GENTIANACEAE } \\
\hline Chelonanthus purpurascens (Aubl.) Struwe, S. Nilsson \& V.A.Albert. & CAM & & $\mathrm{x}$ \\
\hline \multicolumn{4}{|l|}{ HUMIRIACEAE } \\
\hline Vantanea bahiaensis Cuatrec.* & FAN & $\mathrm{x}$ & $\mathrm{x}$ \\
\hline Humiria balsamifera var. parvifolia (Juss.) Cuatr. & FAN & $\mathrm{x}$ & $\mathrm{x}$ \\
\hline
\end{tabular}


Table 1. Continuation.

\begin{tabular}{|c|c|c|c|}
\hline Family/Species & $\mathrm{FV}$ & Gávea & Roxinho \\
\hline \multicolumn{4}{|l|}{ LAURACEAE } \\
\hline Ocotea notata (Nees \& Mart.) Mez ${ }^{*}$ & FAN & & $\mathrm{x}$ \\
\hline Cassytha filiformis $\mathrm{L}$. & LIA & $\mathrm{x}$ & \\
\hline Ocotea lobbii (Meisn.) Rohwer & FAN & $\mathrm{x}$ & \\
\hline \multicolumn{4}{|l|}{ MALPIGHIACEAE } \\
\hline Byrsonima stipulacea (Juss.) Nied. & FAN & & $\mathrm{x}$ \\
\hline Byrsonima sericea DC. & FAN & $\mathrm{x}$ & \\
\hline \multicolumn{4}{|l|}{ MELASTOMATACEAE } \\
\hline Tibouchina urceolaris (Schrank \& Mart. ex DC.) Cogn.* & FAN & $\mathrm{x}$ & $\mathrm{x}$ \\
\hline Pterolepis glomerata Miq. & CAM & $\mathrm{x}$ & \\
\hline Microlicia fulva (Spreng.) Cham. & CAM & $\mathrm{x}$ & \\
\hline Marcetia taxifolia (A.St.-Hil.) DC. & CAM & $\mathrm{x}$ & $\mathrm{x}$ \\
\hline \multicolumn{4}{|l|}{ MYRTACEAE } \\
\hline Calyptranthes brasiliensis Spreng.* & FAN & $\mathrm{x}$ & $\mathrm{x}$ \\
\hline Psidium macahense O. Berg* & & & $\mathrm{x}$ \\
\hline Marlierea neuwiediana (O.Berg) Nied.* & FAN & $\mathrm{x}$ & $\mathrm{x}$ \\
\hline \multicolumn{4}{|l|}{ NYCTAGINACEAE } \\
\hline Guapira opposita (Vell.) Reitz & FAN & & $\mathrm{x}$ \\
\hline Guapira pernambucensis (Casar.) Lundell ${ }^{*}$ & FAN & & $\mathrm{x}$ \\
\hline \multicolumn{4}{|l|}{ OCHNACEAE } \\
\hline Ouratea aff. multiflora (Pohl) Engl.* & FAN & $\mathrm{x}$ & $\mathrm{x}$ \\
\hline \multicolumn{4}{|l|}{ ORCHIDACEAE } \\
\hline Catasetum discolor (Lindl.) Lindl. & & & $\mathrm{x}$ \\
\hline Sobralia sessilis Lindl. & HEM & & $\mathrm{x}$ \\
\hline Sobralia liliastrum Lindl. & HEM & $\mathrm{x}$ & \\
\hline Epistephium lucidum Cogn. & HEM & $\mathrm{x}$ & $\mathrm{x}$ \\
\hline \multicolumn{4}{|l|}{ OROBANCHACEAE } \\
\hline Esterhazya splendida J.C.Mikan & FAN & $\mathrm{x}$ & \\
\hline \multicolumn{4}{|l|}{ PERACEAE } \\
\hline Pera glabrata (Schott) Baill.** & FAN & $\mathrm{x}$ & \\
\hline \multicolumn{4}{|l|}{ POACEAE } \\
\hline Renvoizea trinii (Kunth) Zuloaga \& Morrone & HEM & $\mathrm{x}$ & $\mathrm{x}$ \\
\hline \multicolumn{4}{|l|}{ POLYGALACEAE } \\
\hline Bredemeyera autranii fo. obovata Marques & FAN & & \\
\hline \multicolumn{4}{|l|}{ POLYPODIACEAE } \\
\hline Polypodium latipes Langsd. \& Fisch. & GE & & $\mathrm{x}$ \\
\hline \multicolumn{4}{|l|}{ RUBIACEAE } \\
\hline Pagamea guianensis Aubl. & FAN & $\mathrm{x}$ & $\mathrm{x}$ \\
\hline Emmeorhiza umbellata (Spreng.) Schum. & LIA & & $\mathrm{x}$ \\
\hline Rudgea sp. & FAN & & $\mathrm{x}$ \\
\hline Palicourea blanchetiana Schled. ${ }^{*}$ & FAN & $\mathrm{x}$ & \\
\hline \multicolumn{4}{|l|}{ SAPINDACEAE } \\
\hline Paullinia riodocensis Somner & FAN & & $\mathrm{x}$ \\
\hline \multicolumn{4}{|l|}{ XYRIDACEAE } \\
\hline Xyris ciliata Thunb. & TER & $\mathrm{x}$ & \\
\hline
\end{tabular}

${ }^{*}$ Species with restricted geographic distribution to Mata Atlantica (Stehmann et al. 2009). ${ }^{* *}$ Specie restricted to the Espirito Santo (Fraga 2010). 
(accounting for $54 \%$ of the species at both sites), followed by chamaephytes (accounting for $13 \%$ of the species at the Gávea site and $12 \%$ at the Roxinho site) and hemicryptophytes (accounting for $11 \%$ of the species at the Gávea site and $14 \%$ at the Roxinho site). Epiphytes and geophytes were observed only at the Roxinho site, each accounting for less than $2 \%$ of the species (Tab. 2 and Fig. 2).

In general, phanerophytes were sparsely distributed within both sites. However, we observed some species forming "vegetation islands". For example, shrubs of Humiria balsamifera var. parvifolia had an aggregate distribution with dense populations within the Gávea site, whereas the species occurred in less dense populations or was represented by isolated individuals at the Roxinho site. In contrast, Pagamea guianensis and Tabebuia elliptica had an aggregate distribution at the Roxinho site. This distribution pattern seems to be common in vegetation formations within tabuleiro forests and has been reported for two grassy areas of muçununga in the southern part of Bahia (Meira-Neto et al. 2005), where the most common life forms were phanerophytes in one area and hemicryptophytes in the other. Saporetti Jr. (2009) and Sarcinelli (2010) found that the predominant life forms were in graminoid muçununga and graminoid woody muçununga were chamaephytes and phanerophytes, respectively.

The graminoid layer is characteristic of both sites, with dominance of the hemicryptophytes Lagenocarpus rigidus and Renvoizea trinii, mainly in the dry season, when they become more abundant. According to Walter (1973), the theoretical basis of the classification of vegetation includes the concept that each life form reflects a strategy that was selected by evolutionary pressures and that the composition of a given vegetation formation, in terms of its of life forms, is governed by those strategies. Therefore, a high abundance of hemicryptophyte species indicates the strategy of escaping an unfavorable season, by protecting the buds below the soil
(Pessoa et al. 2004). At the Gávea site, such species cover the soil almost completely during the rainy season, leaving only small depressions where there is upwelling groundwater. At the Roxinho site, hemicryptophytes also cover most of the soil, although less densely, leaving a higher proportion of bare soil. The dominance of hemicryptophyte species is favored by certain characteristics of the families Cyperaceae and Poaceae, which are typical of fields and savannas (Mantovani \& Martins 1993, Batalha \& Martins 2002), such as the ability to establish in open formations and to propagate vegetatively, as well as featuring anemochorous pollination and dispersal (Cabral-Freire \& Monteiro 1993).

\section{Similarities}

Our comparison between the study sites and 18 floristic lists from studies of other vegetation formations that occur on sandy soils, performed with a presence/absence matrix of 767 species, revealed low floristic similarities (Tab. 1 and Fig. 3). The vegetation formations that showed similarities closest to $50 \%$ were muçununga forests and muçununga forests on islands ( $\mathrm{N}$ and $\mathrm{M}$ ) in the southern part of Bahia, followed by the graminoid areas of muçununga of Mucurí and Caravelas. The restingas of the Vale Natural Reserve, Parajú and Barra Seca, were more similar to the Ceolin native field, within the same reserve, and to the shrubland restingas of Linhares, forming a subcluster.

Despite the proximity, the muçununga forest of Linhares was not grouped with the restingas cited or with the Ceolin native field, but rather with the restinga of Setiba, forming an isolated cluster. The muçununga forests of the south of Bahia formed a single cluster. The restingas of Maraú and Salvador formed another isolated cluster, indicating floristic particularities for this region, as noted in other studies (Oliveira-Filho \& Fontes 2000; Marques et al. 2011).

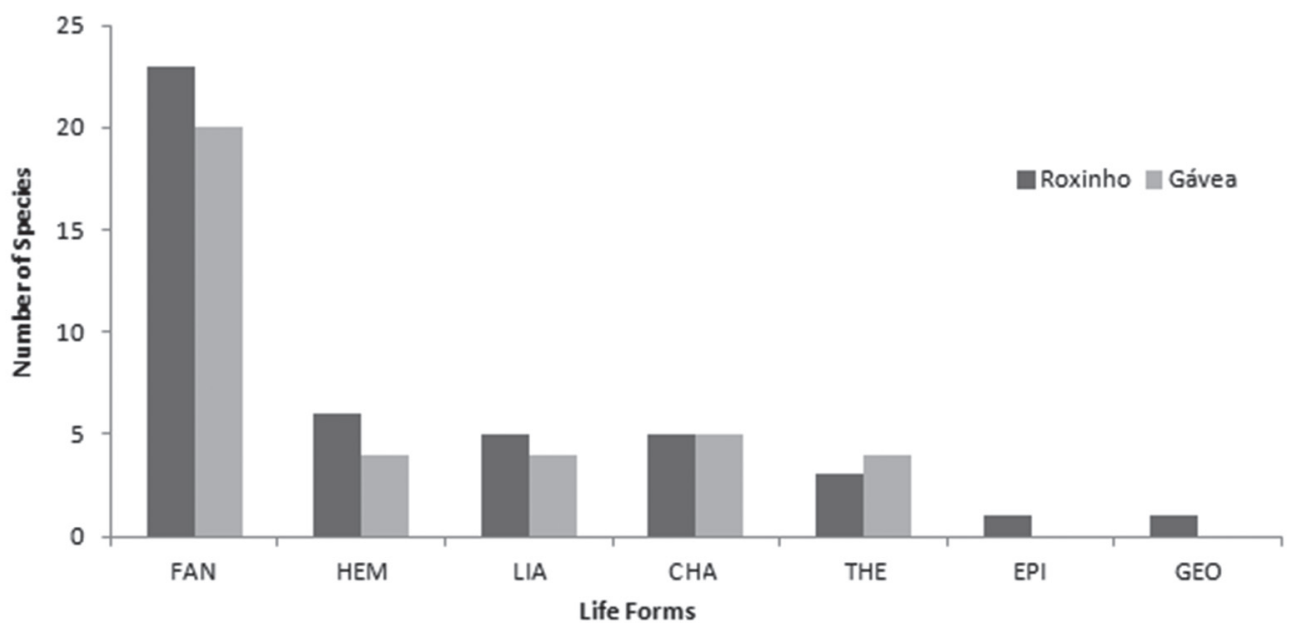

Figure 2. Number of species, by life form, in two formations of native field in the north of the state of Espírito Santo, Brazil.

CHA - chamaephyte; EPI - epiphyte; FAN - phanerophyte; GEO - geophyte; HEM - hemicryptophyte; LIA - liana (creeper); THE - therophyte. 


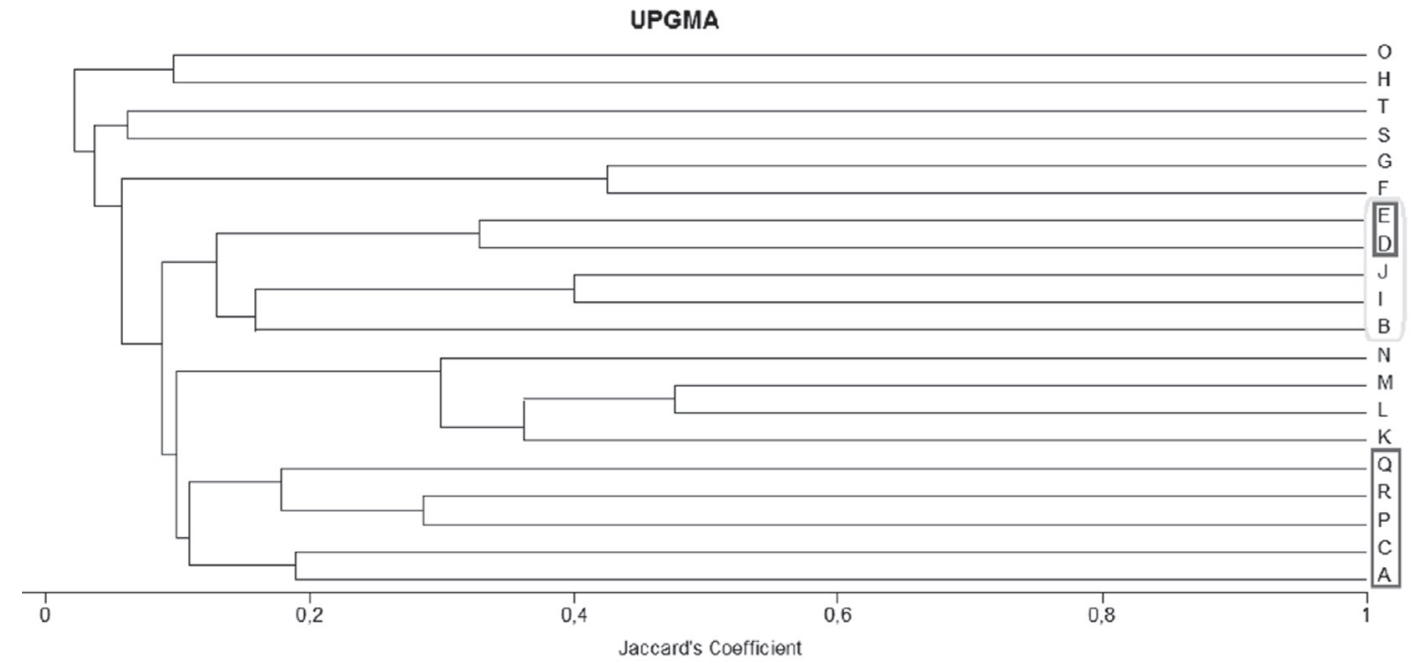

Figure 3. Dendrogram of cluster analysis using the Jaccard similarity index and the unweighted pair group method with arithmetic mean of the floristic data from 20 areas of vegetation on sandy soils in the Brazilian states of Espírito Santo and Bahia.

To identify the areas, see Table 1.

Although muçununga forests are established on Tertiary soils, forming enclaves in the tall tabuleiro forest, their soil conditions are similar to those of the restingas compared here, where the soils are essentially sandy and well-drained (Simonelli et al. 2008). This justifies the position of muçununga forests in the dendrogram, showing higher similarities with restinga forests (Meira-Neto et al. 2005).

The native fields of the Vale Natural Reserve (with the exception of the dense graminoid native field, which remained isolated) and the graminoid areas of muçununga of the south of Bahia formed another cluster. In contrast, the graminoid areas of muçununga of Caravelas and Mucuri (G and F) formed another cluster, revealing their dissimilarity with the cluster of the vegetation formations here studied. The vegetation formations I and J probably show flooding conditions similar to those of the native fields of the Vale Natural Reserve, favoring the common occurrence of species that tolerate the same type of stress. In this case, the low similarity between the two native fields studied (Jaccard similarity index: 33\%) was due to the high proportions of exclusive species found at each site. Our results indicate that this dissimilarity is related to the influence that the nutrient content of the soil, as well as the duration and frequency of soil waterlogging, has on the floristic composition. Differences in the duration of soil waterlogging between vegetation formations usually result in differences in species diversity: species that are dominant in areas subjected to flooding may be rare or absent in drier areas (Gomes et al. 2004). Therefore, variations in the frequency and intensity of soil waterlogging can be considered determinants of the structural and floristic characteristics of the vegetation, potentially altering the behavior of certain populations (Silva et al. 2007). Flooding defines certain abiotic characteristics, both edaphic and microclimatic, which significantly affect biological processes such as decomposi- tion, germination and recruitment of individuals (Lobo \& Joly 2000), thereby defining the spatial distribution of the species within a given vegetation formation.

\section{Water table and soil}

In the comparative analyses of the wells installed within the Roxinho site, we found no significant differences in the water table levels. The same was observed for the Gávea site. However, when comparing the two native fields, we observed significant differences in the mean water table depth $(p<0.001)$, the variation in the mean water table depth between months $(p<0.001)$ and the variation in the mean water table depth between the sites over time $(p<$ 0.001 , interaction between environment and time). During the rainy season, there was upwelling groundwater at the Gávea site, resulting in the formation of a sheet of water of approximately $5 \mathrm{~cm}$ in depth covering the soil, whereas there was no such flooding at the Roxinho site, although the water table was close to the surface there as well. During the dry season (July to October), the water table level at both sites was $\geq 1 \mathrm{~m}$ below the soil.

The soils of the two sites showed sand contents of 99-100\%. According to the Brazilian Agency for Agricultural Research (Embrapa 1999), the soil of the Gávea site is strongly acidic, with a $\mathrm{pH}$ of 4.1-4.6, whereas the soil of the Roxinho site is extremely acidic, with a $\mathrm{pH}<4.1$ (Tab. 3 ). Although both sites have low-fertility soils, the soil of the Roxinho site showed higher levels of macronutrients and micronutrients and was therefore considered more fertile than that of the Gávea site. The cation exchange capacity was also higher in the soil of the Roxinho site, due to the higher organic matter content (Tab. 3). The aluminum saturation was above $50 \%$ at both sites, indicating that their soils can 
Floristic and phytogeographic pattern of native field in southeastern Brazil

Table 3. Comparison between the means of the soil chemical variables found in 20 sampling units in two areas of native field in the Reserva Natural Vale, Linhares, ES. The numbers are means \pm standard deviation and, in parentheses, the coefficient of variation.

\begin{tabular}{|c|c|c|c|}
\hline Variables & Gávea & Roxinho & $\mathrm{F}$ \\
\hline $\mathrm{pH}\left(\mathrm{H}^{2} \mathrm{O}\right)$ & $4,23 \pm 0,14(3,36)$ & $3,91 \pm 0,11(2,92)$ & $30.81^{*}$ \\
\hline $\mathrm{P}\left(\mathrm{mg} / \mathrm{dm}^{3}\right)$ & $2,40 \pm 0,37(15,41)$ & $6,65 \pm 0,90(13,59)$ & $189.93^{*}$ \\
\hline $\mathrm{K}\left(\mathrm{mg} / \mathrm{dm}^{3}\right)$ & $10 \pm 0,00(0,00)$ & $33,33 \pm 4,44(13,33)$ & $275.63^{*}$ \\
\hline $\mathrm{Na}\left(\mathrm{mg} / \mathrm{dm}^{3}\right)$ & $9,13 \pm 1,85(20,27)$ & $20,33 \pm 3,67(18.04)$ & $74.36^{*}$ \\
\hline $\mathrm{Ca}\left(\mathrm{cmolc} / \mathrm{dm}^{3}\right)$ & $0,12 \pm 0,04(31,34)$ & $0,37 \pm 0,13(34,55)$ & $33.75^{*}$ \\
\hline $\mathrm{Mg}\left(\mathrm{cmolc} / \mathrm{dm}^{3}\right)$ & $0,36 \pm 0,08(23,01)$ & $0,72 \pm 0,10(14,25)$ & $75.46^{*}$ \\
\hline $\mathrm{Al}\left(\mathrm{cmolc} / \mathrm{dm}^{3}\right)$ & $1,05 \pm 0,09(8,52)$ & $1,47 \pm 1,16(10,82)$ & $53.24^{*}$ \\
\hline $\mathrm{H}+\mathrm{Al}\left(\mathrm{cmolc} / \mathrm{dm}^{3}\right)$ & $5,38 \pm 1,58(29,32)$ & $18,99 \pm 0,34(16,02)$ & $157.93^{*}$ \\
\hline $\mathrm{MO}(\mathrm{dag} / \mathrm{Kg})$ & $5,16 \pm 0,88(16,99)$ & $6,65 \pm 0,61(9,23)$ & $19.19^{*}$ \\
\hline $\mathrm{Fe}\left(\mathrm{mg} / \mathrm{dm}^{3}\right)$ & $2,5 \pm 0,51(20,22)$ & $3,38 \pm 0,80(23,52)$ & $8.78^{* *}$ \\
\hline $\operatorname{Mn}\left(\mathrm{mg} / \mathrm{dm}^{3}\right)$ & $0,13 \pm 0,04(26,35)$ & $0,48 \pm 0,34(70,58)$ & $10.42^{* *}$ \\
\hline $\mathrm{Zn}\left(\mathrm{mg} / \mathrm{dm}^{3}\right)$ & $0,28 \pm 0,10(36,89)$ & $0,52 \pm 0,14(26,03$ & $19.15^{\star}$ \\
\hline CTC $\left(\mathrm{cmolc} / \mathrm{dm}^{3}\right)$ & $1,59 \pm 0,18(11,32)$ & $2,73 \pm 0,36(13,10)$ & $80.53^{*}$ \\
\hline m - saturação por alumínio (\%) & $66,18 \pm 3,85(5,82)$ & $54,10 \pm 2,71(2,24)$ & $65.61^{\star}$ \\
\hline v - saturação de bases (\%) & $10,31 \pm 2,16(20,97)$ & $6,77 \pm 2,24(32,99)$ & $12.96^{* *}$ \\
\hline
\end{tabular}

${ }^{*} \mathrm{P}<0,001,{ }^{* *} \mathrm{P}<0,01$

be considered Al-saturated-extremely poor soils with high aluminum saturation (Ronquim 2010). There were significant differences between the two sites regarding the soil chemical variables analyzed.

In summary, soil waterlogging was the main abiotic factor, selecting the occurrence of plant species, which resulted in a reduction of the diversity of the native fields. The differences in the frequency and duration of soil waterlogging were responsible for the floristic differences found between the two areas, and acted on the selection of species to such a degree that each area had a group of exclusive species. Despite the low floristic similarity, both areas showed a life form spectrum that supports their classification into the same vegetation formation.

The proximity between the native fields studied and areas of muçununga did not increase the floristic similarity between the two, and the muçununga was not the main source of propagules for the native fields. The floristic similarity between the native fields of the Vale Natural Reserve and the graminoid areas of muçununga in the southern part of Bahia seems to indicate that they are in fact the same type of vegetation formation, despite the distinct designations, and that, in the future, the classification should be standardized to facilitate more robust comparisons.

\section{Acknowledgments}

This study received financial support from the Brazilian Coordenação de Aperfeiçoamento de Pessoal de Nível Superior (CAPES, Office for the Advancement of Higher Education) and Conselho Nacional de Desenvolvimento Científico e Tecnológico (CNPq, National Council for Scientific and Technological Development). We are grateful to the Vale Company, for authorizing access to the study areas, and to the entire team that collaborated on this study.

\section{References}

Almeida Jr.E.B.; Olivo, M.A.; Araújo, E.L. \& Zickel, C.S. 2009. Caracterização da vegetação de restinga da RPPN de Maracaípe, PE, Brasil, com base na fisionomia, flora nutrientes do solo e lençol freático. Acta Botanica Brasilica 23: 36-48

Amaral, D.D.; Prost, M.T.; Bastos, M.N.C.; Neto, S.V.C. \& Santos, J.U.M. 2008. Restingas do litoral amazônico, estados do Pará e Amapá, Brasil. Boletim do Museu Paraense Emílio Goeldi, Ciências Naturais 3: 35-67.

APG III. 2009. An update of the Angiosperm Phylogeny Group classification for the orders and families of flowering plants. Botanical Journal of the Linnaean Society 161:105-202.

Araújo, D.S.D.; Pereira O.J. \& Peixoto A.L. 2008. Campos nativos at the Linhares forest reserve, Espírito Santo, Brazil. Memoirs of the New York Botanical Garden 100: 371-385.

Assis, A.M.; Thomaz, L.D. \& Pereira, O.J. 2004. Florística de um trecho de floresta de Restinga no município de Guarapari, Espírito Santo, Brasil. Acta Botanica Brasilica 18: 191-201.

Batalha, M.A. \& Martins, F.R. 2002. The vascular flora of Cerrado in Emas National Park (Goiás, Central Brazil). SIDA 20: 295-311.

Cabral-Freire, M.C.C. \& Monteiro, R. 1993. Florística das praias da Ilha de São Luís, Estado do Maranhão (Brasil): diversidade de espécies e suas ocorrências no litoral brasileiro. Acta Amazonica 23: 125-140.

Chatfield, C. \& Collins, A.J. 1983. Introduction to multivariate analysis. London, Chapman and Hall.

Damasceno Junior, G.A.; Semir, J.; Santos, F.A.M. \& Leitão-Filho, H.F. 2005. Structure, distribuition of species and inundation in riparian Forest of Rio Paraguai, Pantanal, Brazil. Flora, 200: 119-135.

EMBRAPA - Empresa Brasileira de Pesquisa Agropecuária. 1997. Manual de métodos de análises de solo. 2 . ed. Rio de Janeiro, Ministério da Agricultura e do Abastecimento. 
EMBRAPA - Empresa Brasileira de Pesquisa Agropecuária. 1999. Sistema brasileiro de classificação de solos. Brasília: Embrapa.

Felfili, J.M. 1995. Diversity, structure and dynamics of a gallery forest in central Brazil. Vegetatio 117: 1-15.

Garay, I. 2003. Uma história recente. Pp. 3-26. In: Garay, I \& Rizzini, C.M (Orgs.) A Floresta Atlântica de Tabuleiros. Diversidade funcional e cobertura arbórea. Petrópolis, Vozes.

Gomes, B.Z.; Martins, F.R. \& Tamashiro, J.Y. 2004. Estrutura do cerradão e da transição entre cerradão e floresta paludícula num fragmento da International Paper do Brasil Ltda. em Brotas, SP. Revista Brasileira de Botânica 27: 249-262.

Guedes, D.; Barbosa, L.M. \& Martins, S.E. 2006. Composição florística e estrutura fitossociológica de dois fragmentos de floresta de Restinga no Município de Bertioga, SP, Brasil. Acta Botanica Brasilica 20: 299-311.

Heinsdijk, D.; Macedo, J.G.; Andel, S. \& Ascoly, R.B. 1965. A floresta do norte do Espírito Santo. Boletim do Setor de Inventário Florestal. 7: 1-69.

Ivanauskas, N.M.; Rodrigues, R.R. \& Nave, A.G. 1997. Aspectos ecológicos de uma mata de brejo em Itatinga, SP: florística, fitossociologia e seletividade de espécies. Revista Brasileira de Botânica 20: 139-153.

Jesus, R.M. \& Rolim, S.G. 2005. Fitossociologia da Floresta Atlântica de Tabuleiro. Boletim Técnico SIF 19: 1-149.

Jesus, R.M.; Rodrigues, F.C.M.P. \& Rolim, S.G. 2010. Pesquisas em sementes florestais na Reserva Natural Vale. v.1 edição. Rio de Janeiro. Editora Movimentos Artes Gráficas Ltda.

Joly, C. A. \& Crawford, M.M. 1982. Variation in tolerance and metabolic responses to flooding in some tropical trees. Journal of Experimental Botany 33: 799-809.

Joly, C.A. 1991. Flooding tolerance in tropical trees. Pp. 23-24. In: M. B. Jackson, D. D. Davies \& H. Lambers (Eds.). Plant life under oxygen deprivation: ecology, physiology and biochemistry. Hague, SBP Academic Publishing.

Junk, W.J.; Bayley, P.B. \& Sparks, R.E. 1989. The flood pulse concept in river-floodplain systems. Canadian Journal of Fishers and Aquatic 106: 110-127.

Kent, M. \& Coker, P. 1992. Vegetation Description and Analysis. Belhaven Press. London.

Köppen, W. 1946. Das geographische System der Klimate. In: Köppen, W. \& Geiger, W., (eds). Handbuch der Klimatologie. Berlin, Gebr. Borntrager

Lieberman, D.; Lieberman, M.; Peralta, R. \& Hartshorn, G.S. 1985. Mortality patterns and stand turnover rates in a wet tropical forest in Costa Rica. Journal of Ecology 73:915-924.

Lobo, P.C. \& Joly, C.A. 2000. Aspectos ecofisiológicos da vegetação de mata ciliar do sudeste do Brasil. Pp. 143-167. In: R.R. Rodrigues \& H.F. Leitão Filho (eds). Matas ciliares: conservação e recuperação. São Paulo, Universidade de São Paulo.

Loures, L.; Carvalho, D.A.; Machado, E.L.M. \& Marques, J.J.G.S.M. 2007. Florística, estrutura, e características do solo de um fragmento de floresta paludosa no sudese do Brasil. Acta Botanica Brasilica 21: 885-896.

Mantovani, W. \& Martins, F.R. 1993. Florística do cerrado da Reserva Biológica de Moji Guaçu, SP. Acta Botanica Brasilica 7: 33-60.

Marques, M.C.M.; Swaine, M.D. \& Liebsch, D. 2011. Diversity distribution and floristic diferentiation of the coastal lowland vegetation: implications for the conservation of the Brazilian Atlantic Forest. Biodiversity \& Conservation 20: 153-168.

Meira Neto, J.A.A.; Souza, A.L.; Lana, J.M. \& Valente, G.E. 2005. Composição florística, espectro biológico e fitofisionomia da vegetação de muçununga nos municípios de Caravelas e Mucuri, Bahia. Revista Árvore 29: 139-150.

Megonigal, J.P.; Conner, W.H.; Kroeger S. \& Sharitz, R.R. 1997. Aboveground production in southeastern floodplain forests: a test of the subsidy-stress hypothesis. Ecology 78: 370-384.

Menezes, L.F.T.; Araujo, D.S.D. \& Nettesheim, F.C. 2010. Estrutura comunitária e amplitude ecológica do componente lenhoso de uma floresta de restinga mal drenada no sudeste do Brasil. Acta Botanica Brasilica 24: 825-839.

Mori, S.A. Silva, L.A.M. Lisboa, G. \& Coradin, L. 1989. Manual de manejo do herbário Manual de manejo do herbário fanerogâmico. Ilhéus, Centro de Pesquisa do Cacau.
Mueller-Dombois, D. \& Ellenberg, H. 1974. Aims and methods of vegetation ecology. New York, John Wiley \& Sons.

Odum, E. P., Finn, J.T., Franz, E. H. 1979. Perturbation theory and thesubsidy-stress gradient. BioScience 29: 349-352.

Oliveira-Filho, A.T.; Shepherd, G.J.; Martins, F.R. \& Stubblebine, W.H. 1990. Environmental factors affecting physiognomic and floristic variation in an area of cerrado in central Brazil. Journal of Tropical Ecology 5: 413-451.

Oliveira-Filho, A.T. \& Fontes, M.A.L. 2000. Patterns of floristic diferentiation among Atlantic forests in Southeastern Brazil and the influence of climate. Biotropica 32: 793-810.

Pagano, S.N. \& Durigan, G. 2000. Aspectos da ciclagem de nutrientes em matas ciliares do oeste do estado de São Paulo, Brasil. Pp. 109123. In: Rodrigues, R.R.\& Leitão-Filho, H.F. (eds.). Matas ciliares: Conservação e recuperação. São Paulo, Universidade de São Paulo.

Peixoto, A.L. \& Gentry. A. 1990. Diversidade e composição florística da Mata de Tabuleiro na Reserva Florestal de Linhares (Espírito Santo, Brasil). Revista Brasileira de Botânica 13: 19-25.

Peixoto, A.L. 1982. Considerações Preliminares sobre a flora e a vegetação da Reserva Florestal da CVRD (Linhares - ES). Universidade Federal do Piauí. Cadernos de Pesquisa Série Botânica 1: 41-48.

Peixoto, A.L.; Silva, I.M.; Pereira, O.J.; Simonelli, M.; Jesus, R.M. \& Rolim, S.G. 2008. Tableland Forests North of the Rio Doce: Their Representation in the Linhares Forest Reserve, Espirito Santo State, Brazil. Memoirs of the New York Botanical Garden 100: 369-372.

Pereira, O.J. \& Araujo, D.S.D. 2000. Análise florística das restingas dos estados do Espírito Santo e Rio de Janeiro. Pp. 25-63. In: Esteves, F.A \& Lacerda, L.D. (orgs.). Ecologia de restingas e lagoas costeiras. Macaé, NUPEM/UFRJ.

Pessoa, L.M.; Rodal, M.J.N.; Lins e Silva, A.C.B.L. \& Costa, K.C.C. 2004 Levantamento da flora herbácea em um trecho de caatinga, RPPN Maurício Dantas, Betânia/Floresta, Pernambuco. Revista Nordestina de Biologia 18: 27-53.

Rocha, C.T.V.; Carvalho, D.A.; Fontes, M.A.L.; Oliveira Filho, A.T.; van den Berg, E. \& Marques, J.J.G.S.M. 2005. Comunidade arbórea de um continuum entre floresta paludosa e de encosta em Coqueiral, Minas Gerais, Brasil. Revista Brasileira de Botânica 28: 203-218.

Rodrigues, R.R. \& Shepherd, G.J. 2000. Fatores condicionantes da vegetação ciliar. Pp. 101-108. In: Rodrigues, R.R. \& Leitão-Filho, H.F. (eds.) Matas ciliares: Conservação e recuperação. São Paulo, Universidade de São Paulo.

Ronquim, C.C. 2010. Conceitos de fertilidade do solo e manejo adequado para as regiões tropicais. Campinas, SP: Embrapa Monitoramento por Satélite. Embrapa Monitoramento por Satélite. Boletim de Pesquisa e Desenvolvimento 8: 26

Santos, R.D.; Barreto,W.O.; Silva, E.F.; Araújo; Wilson, S.; Claessen, M.E.C.; Paula, J.L.; Souza, J.L.R.; Pérez, D.V. \& Souza, J.S. 2004. Levantamento expedito dos solos das reservas florestais de Linhares e Sooretama no estado do Espírito Santo. Rio de Janeiro: Embrapa Solos. Boletim de Pesquisa e Desenvolvimento 49: 66

Saporetti-Júnior, A.W. 2009. Vegetação e solos de muçununga em Caravelas, Bahia. Tese (Doutorado em Botânica). Universidade Federal de Viçosa, Viçosa. 139p

Sarcinelli, T.S. 2010. Muçunungas: Enclaves de vegetação arenícola na Floresta Atlântica de Tabuleiros. Tese (Doutorado em Solo e Nutrição de Plantas). Viçosa, Universidade Federal de Viçosa.

Scarano, F.R. 1998. A comparison of dispersal, germination and establishment of woody plant subject to distinct flooding regimes in Brazilian flood-plane forests estuarine vegetation. Oecologia Brasiliensis 4 177-194.

Scarano, F.R.; Ribeiro, K.T.; Moraes, L.F.D.; Lima, H.C. 1997. Plant establishment on flooded and unflooded patches of a freshwater swamp forest in southeastern Brazil. Journal of Tropical Ecology. 14: 793-803.

Scarano, F.R. 2002. Structure, function and floristic relationships of plant communities in stressful habitats marginal to the Brazilian Atlantic rainforest. Annals of Botany. 90: 517-524.

Scarano, F.R. 2006. Plant community structure and function in a swamp forest within the Atlantic rain forest complex: a synthesis. Rodriguésia 57: 491-502. 
Scarano, F.R.; Duarte, H.M.; Franco, A.C.; Mattos, E.A.; Rennenberg, H.; Lüttge, U. \& Gessler, A. 2005. Physiological synecology of tree species in relation to geographic distribution and ecophysiological parameters at the Atlantic forest periphery in Brazil: an overview. Trees-Structure and Function 19: 493-496.

Scherer, A.; Maraschin-Silva, F. \& Baptista, L.R.M. 2005. Florística e estrutura do componente arbóreo de matas de restinga arenosa no Parque Estadual de Itapuã, RS, Brasil. Acta Botanica Brasilica 19: 717-727.

Silva, A.C.; Berg, E.V.D.; Higuchi, P. \& Oliveira-Filho, A.T. 2007. Composição florística de florestas inundáveis das regiões sudeste e sul do Brasil. Revista Brasileira de Botânica 30: 257-269.

Simonelli, M.; Souza A.L.; Peixoto, A.L. \& Silva, A.F. 2008. Floristic Composition and Structure of the Tree Component of a Muçununga Forest in the Linhares Forest Reserve, Espírito Santo, Brazil. Memoirs of the New York Botanical Garden 100: 345-364.

Souza, A.F. \& Martins, F.R. 2005. Spatial variation and dynamics of flooding, canopy openness, and structure in a Neotropical swamp forest. Plant Ecology 180: 161-173.

Suguio, K.; Martin, L. \& Dominguez, J.M.L. 1982. Evolução do delta do rio Doce (ES) durante o quaternário: influência das variações do nível do mar. Pp. 93-116. In: Suguio, K.; Meis, M.R. M. \& Tessler, M.G. (eds.). Atas IV Simpósio Quaternário do Brasil. Rio de Janeiro, Sociedade Brasileira de Geologia.
Teixeira, A.P \& Assis, M.A. 2009. Relação entre heterogeneidade ambiental e distribuição de espécies em uma floresta paludosa no Município de Cristais Paulista, SP, Brasil. Acta Botanica Brasilica 23: 843-853.

Teixeira, A.P.; Assis, M.A.; Siqueira, F.R. \& Casagrande, J.C. 2008. Tree species composition and environmental relationships in a Neotropical swamp forest in Southeastern Brazil. Wetlands Ecology and Management 16: 451-461.

The angiosperm phylogeny group. 2009. An update of the Angiosperm Phylogeny Group classification for the orders and families of flowering plants: APG III. Botanical Journal of the Linnean Society 161 : 105-121.

Veloso, H.P. \& Góes-Filho, E.L. 1982. Fitogeografia Brasileira, classificação fisionômico-ecológica da vegetação neotropical. Boletim Técnico do Projeto RADAMBRASIL (Série Vegetação) 1: 3-79.

Veloso, H.P.; Rangel Filho, A.L.R. \& Lima, J.C.A. 1991. Classificação da vegetação brasileira adaptada a um sistema universal. Rio de Janeiro, IBGE.

Walter, H. 1973. Vegetation of the earth in relation to the eco-physiological conditions. New York, Springer Verlag.

Zar, J.H. 1996. Biostatistical analysis. Third edition. New Jersey. PrenticeHall International Editions. 